Review Article

\title{
The Association between Type 2 Diabetes Mellitus and Women Cancer: The Epidemiological Evidences and Putative Mechanisms
}

\author{
Kyong Hye Joung, ${ }^{1}$ Jae-Wook Jeong, ${ }^{2}$ and Bon Jeong Ku${ }^{1}$ \\ ${ }^{1}$ Department of Internal Medicine, Chungnam National University School of Medicine, 282 Munhwa-ro, Jung-gu, \\ Daejeon 301-721, Republic of Korea \\ ${ }^{2}$ Department of Obstetrics, Gynecology and Reproductive Biology, Michigan State University, College of Human Medicine, \\ 333 Bostwick Avenue NE, Grand Rapids, MI 49503, USA \\ Correspondence should be addressed to Jae-Wook Jeong; jaewook.jeong@hc.msu.edu and Bon Jeong Ku; bonjeong@cnu.ac.kr
}

Received 24 June 2014; Revised 12 September 2014; Accepted 8 October 2014

Academic Editor: Viroj Boonyaratanakornkit

Copyright (C) 2015 Kyong Hye Joung et al. This is an open access article distributed under the Creative Commons Attribution License, which permits unrestricted use, distribution, and reproduction in any medium, provided the original work is properly cited.

Type 2 diabetes mellitus (T2DM), a chronic disease increasing rapidly worldwide, is well established as an important risk factor for various types of cancer. Although many factors impact the development of T2DM and cancer including sex, age, ethnicity, obesity, diet, physical activity levels, and environmental exposure, many epidemiological and experimental studies are gradually contributing to knowledge regarding the interrelationship between DM and cancer. The insulin resistance, hyperinsulinemia, and chronic inflammation associated with diabetes mellitus are all associated strongly with cancer. The changes in bioavailable ovarian steroid hormone that occur in diabetes mellitus (the increasing levels of estrogen and androgen and the decreasing level of progesterone) are also considered potentially carcinogenic conditions for the breast, endometrium, and ovaries in women. In addition, the interaction among insulin, insulin-like growth factors (IGFs), and ovarian steroid hormones, such as estrogen and progesterone, could act synergistically during cancer development. Here, we review the cancer-related mechanisms in T2DM, the epidemiological evidence linking T2DM and cancers in women, and the role of antidiabetic medication in these cancers.

\section{Introduction}

Diabetes mellitus (DM), mostly type 2 diabetes mellitus (T2DM), is one of the most common chronic diseases characterized by hyperglycemia. The World Health Organization (WHO) announced that the worldwide prevalence of DM in 2000 was 171 million and would reach approximately 366 million by 2030 [1]. However, the worldwide prevalence of DM has already reached 346 million as of 2010 [2]. The exponential growth and future burden of the high DM prevalence are responsible for most of the mortality and morbidity rates worldwide $[3,4]$. Therefore, many studies have investigated the association and effects between DM and DM-related disease extensively, particularly the relationship between T2DM and cancer [5-8]. The recent consensus report sponsored by the American Association of Clinical Endocrinologists and the American College of Endocrinology (AACE/ACE Consensus Statement) highlighted that large and systemic studies are needed to investigate the relationship between T2DM and cancer [9].

The association between T2DM and cancer was reported more than 100 years ago [10]. Most epidemiological studies have suggested that cancers, particularly hepatic, pancreatic, colorectal, bladder, endometrial, and breast cancers, appear to be associated with T2DM, increasing the risk and mortality rates $[1,3,6,11-20]$. Each value of the estimated risk may differ because of the impact of variable and intermingling factors, such as ethnic differences-including genetic susceptibility, life-style behavior, and environmental exposure-across populations [21]. However, recent studies have suggested that variable biological effects of diabetes may act synergistically with other definite cancer risk factors, particularly with 
ovarian steroid hormones [21-25]. Although the different impacts of ovarian steroid hormones and biological differences between males and females may lead to variations in cancer incidence, prognosis, and clinical outcomes, dedicated research on the effects of T2DM and cancer in females is limited.

In the present review, we will discuss the epidemiological evidence and possible mechanisms behind the relationship between T2DM and cancer in women, as well as the effect of diabetes treatments on cancer incidence and comorbidity.

\section{Mechanisms of Carcinogenesis in Diabetes Mellitus}

Carcinogenesis is a multistep process that undergoes various genetic "hits," and diabetes may influence these processes by several mechanisms, particularly in females. DM and cancer share several common mechanisms, including increased insulin and insulin-like growth factor (IGF) signaling, dysregulation of ovarian steroid hormones, and chronic inflammation.

2.1. Insulin/IGF Signaling. Insulin and IGFs are well known for their involvement in cell survival and proliferation, as well as carbohydrate metabolism [26]. Unlike epidermal growth factor (EGF) and platelet-derived growth factor, which play roles at the cellular or tissue level as autocrine or paracrine factors, insulin and IGFs play important systemic regulatory roles at the whole organism level as a hormone [27-29]. Insulin and IGFs show hormonal effects through the insulin receptor (IR) and IGF receptors (IGFRs), which are widely expressed in normal tissues [30,31]. Both types of receptors are membrane receptors with the tyrosine kinase domain located inside the cell membrane [32]. In terms of biological activity, these receptors form a holoreceptor characterized by two "half receptors", which comprise an extracellular $\alpha$-chain and an intracellular $\beta$-chain [32]. Half receptors of insulin exist as two splice variant isoforms, "A" and "B." While the " $B$ " [33] isoform recognizes only insulin, the " $A$ " isoform recognizes both insulin and IGF-2 and is expressed most commonly by cancer cells [34]. The half IR and half IGF-1 receptor (IGF1R) can interact and form tetrameric structures known as "hybrid receptors," which exert similar, but not identical, downstream signaling to that of IR or IGF1R [3436]. Autoregulated or ligand-recognized IRs activate insulin receptor substrates (IRS) through tyrosine phosphorylation, thereby activating the phosphatidylinositol 3-kinase (PI3K) pathway and Ras/mitogen-activated protein kinase (MAPK) pathway known as mitogenic signaling by insulin [34].

Many epidemiological studies have suggested that insulin and IGF-1 play important roles in the regulation of cancer. An increased insulin or IGF-1 level, which presents in T2DM, obesity, and acromegaly, is strongly associated with increased cancer risk and mortality [37-41]. Some studies have shown evidence that the rates of insulin secretion among individuals may influence the risk and progression of cancer [42, 43]. Additionally, the insulin and IGF-1 levels in cancer patients are proportional to cancer-related mortality [26, 44]. Many in vitro and in vivo studies have shown evidence supporting epidemiological studies. For example, insulin or IGF-1 increased cell proliferation and reduced apoptosis in cancer cells, even at physiologically relevant concentrations $[45,46]$. On the other hand, insulin signaling deficiency caused by the downregulation of IRs was shown to inhibit the proliferation and metastasis of cancer cells in vitro and in vivo [47, 48]. Insulin has direct access to its receptors, but most circulating IGFs are bound to IGF binding proteins (IGFBPs) and thereby demonstrate limited and attenuated IGFR-mediated bioactivity [49]. Therefore, the biological activity of IGFs may be determined by the level of IGFBPs, which are influenced by various conditions associated with insulin resistance such as T2DM and obesity [50-52]. Insulin resistance and increased insulin levels are associated with increased risk and mortality in women with cancer, particularly breast, endometrial, and ovarian cancers [53-55].

Although mainstream studies have suggested that insulin and IGFs are associated strongly with cancer development, each study showed a different degree of cancer risk associated with insulin and IGFs [33]. The latter view may be due to the following reasons. First, the functional differences in receptors may be due to the various types of tyrosine kinases, leading to phosphorylation of different IRS members. Therefore, insulin and IGFs may lead to various effects depending on the combination of half receptors in cancer cells. Second, the insulin and IGF cancer-related signaling pathways have adapted from those of normal cells, particularly from insulinsensitive tissues such as the liver, muscle, and adipose tissue. However, the internal signals of a cancer cell are very different from those of normal cells because of the changes in genetic and/or epigenetic factors, thereby stimulating another signaling pathway in response to insulin and IGF. Therefore, insulin and IGFs may induce a cancer cell-specific signaling pathway aberrant from that of normal cells $[26,56]$.

2.2. Ovarian Steroid Hormone/Sex Hormone-Binding Globulin Regulation. The ovarian steroid hormones are some of the most common types of hormones related to cancer generation and/or progression. The predominating theories suggest that the ovarian steroid hormones estrogen and progesterone have a strong association with endometrial, breast, and ovarian cancers [57-59]. Enhanced signaling by estrogen in particular has been considered a risk factor for females with cancer. This is based on the observation that the estrogen increase and endometrial proliferation rate during the follicular phase of the menstrual cycle drive ductal elongation in mammary gland development during puberty [60-62].

Epidemiological studies have demonstrated that postmenopausal women are at an increased risk of cancers from exogenous estrogen replacement without progesterone [63-69]. Other studies have shown that polycystic ovarian syndrome (PCOS) in premenopausal women is very closely related to increased cancer risk and results from increased androgen and decreased progesterone levels [70-74]. The sex hormone-binding globulin (SHBG) level is one of the most important factors in cancer generation and/or development 
in postmenopausal women because its reduction leads to an increase in free ovarian steroid hormones [75-82].

Estrogen in cancer cells may trigger proliferation and cellular growth through the activation of estrogen receptor alpha $(\mathrm{ER} \alpha)$ following the activation of PI3K and MAPK pathways $[83,84]$. The role of estrogen is important because ovarian steroid hormone-sensitive tissues responding to ovarian steroid hormones exhibit increased levels of bioactive IGF-1 and gene expression of IGF1R, IRS-1, and IRS-2 [8587]. In addition, activation of IR and IGF1R induces the phosphorylation of $\mathrm{ER} \alpha$, thereby potentiating $\mathrm{ER} \alpha$ signaling $[88,89]$. Therefore, cancer cells expressing higher levels of IR and/or IGF1R would result in resistance to antiestrogen therapy such as tamoxifen [89-91]. Although the role of androgen in promoting carcinogenesis and cell proliferation is well known in prostate cancer, in vitro studies have suggested that androgen could affect cell viability and proliferation through the regulation of inflammatory and Notch signaling pathways $[92,93]$.

Interestingly, hyperinsulinemia and/or insulin resistance, particularly in postmenopausal females with T2DM, result in increased bioavailable ovarian steroid hormone levels through suppressed hepatic SHBG production and induced ovarian steroid hormone production [23, 85, 94-97]. Additionally, the increased insulin and IGF-1 levels in females with T2DM potentiate ER $\alpha$ signaling by IR and/or IGF1R. Such observation and prediction suggest that diabetes, particularly T2DM, may involve cancer generation and/or development mechanisms through abnormal sex hormone signaling.

2.3. Chronic Inflammation. Most of our current knowledge indicates that the net effect of inflammation is the triggering of cancer development and progression [98-102]. Mediators of inflammatory pathways such as interleukin-6 (IL-6), tumor necrosis factor alpha (TNF $\alpha)$, and cyclooxygenase2 (COX-2) are involved in cancer-related mechanisms that diminish tumor suppressor function, stimulate oncogene expression, and increase cell cycling [103]. Conversely, inhibition of inflammatory signaling such as that by nuclear factor kappa-light-chain-enhancer of activated B cell (NF$\kappa \mathrm{B})$ reduces cancer incidence $[104,105]$. Additionally, many studies concerning the association of inflammation and cancer in females suggest that the inflammatory pathways activated through $\mathrm{NF}-\kappa \mathrm{B}$ signaling play an important role in the development and progression of cancers such as breast, endometrial, and ovarian cancers [106-109].

Insulin resistance and hyperinsulinemia in T2DM promote subclinical or low-grade chronic inflammation that aggravates insulin resistance $[110,111]$. Ovarian steroid hormones, particularly estrogen, can activate NF- $\kappa \mathrm{B}$ signaling, which induces the gene expression of inflammatory mediators such as IL-1, TNF $\alpha$, and metalloproteinases (MMPs), thereby facilitating inflammatory processes [108, 112, 113]. As noted above, females with T2DM-increased bioavailable ovarian steroid hormones show more enhanced inflammatory effects. Therefore, a chronic inflammatory state in these patients may be the main mechanism associated with cancer development and progression.

\section{The Link between Diabetes Mellitus and Cancer in Women}

The risk of cancers in the female reproductive organs is increased in T2DM. Both breast and endometrial cancer risks are increased in diabetic females. Several biological mechanisms may be involved, mostly regarding ovarian steroid hormone abnormalities.

3.1. Breast Cancer. T2DM and breast cancer are both serious life-threatening diseases globally. Breast cancer, the most common cancer and second leading cause of cancer-related death in women, shares some risk factors with diabetes, such as age and obesity $[114,115]$. Female diabetic patients were more likely to have increased risk of and mortality from breast cancer [3, 116-118]. A meta-analysis of 20 studies (five casecontrol and 15 cohort studies between 1966 and February 2007) indicated that females diabetics had an increased risk of breast cancer with a relative risk (RR) of 1.20 [95\% confidence interval (CI): 1.12-1.28] [11]. A recently conducted metaanalysis of 12 studies (five case-control and seven cohort studies between 2000 and March 2010) showed a similar result in which women with diabetes have a significantly increased risk of breast cancer with a summary RR of 1.72 (95\% CI: 1.47-2.00). Additionally, among postmenopausal or postmenopausal-age females, a strong relationship was demonstrated between diabetes and breast cancer with a summary RR of 1.25 (95\% CI: 1.20-1.29) [119]. The Cancer Prevention Study II demonstrated that the incidence of diabetes in females was associated significantly with a $16 \%$ increased mortality from breast cancer with an age-adjusted RR of 1.24 (95\% CI: 1.11-1.39) and multivariable-adjusted RR of 1.16 (95\% CI: 1.03-1.29) [3]. These findings are similar to those of two retrospective cohort studies in the United Kingdom (UK) and Taiwan. Data in the UK study showed a reduced survival time for women with both diabetes and breast cancer (nondiabetes versus diabetes, 14.3 versus 10.4 years, resp.) [117]. In the Taiwan study, breast cancer patients with diabetes had a significantly increased mortality with a hazard ratio (HR) of 1.57 (95\% CI: 1.15-2.15) [118].

In breast cancer, insulin and IGFs play important roles as mitogens. Breast cancer tissues showed increased levels of the " $A$ " isoform of the IR (IR-A) activated by insulin and IGF [120]. PI3K and/or Ras/MAPK pathways induced through IRA activation resulted in mitosis of breast cancer cells in vitro [53]. In vivo studies using nonobese, insulin-resistant, and hyperinsulinemic transgenic MKR mouse models showed that hyperinsulinemia results in mammary ductal hyperplasia and IR-expressing carcinoma [121]. Women with diabetes displayed hormonal changes resulting from increased production of estrogen and androgen with decreased liver production of SHBG [122]. These hormonal changes were also strongly associated with breast cancer risk in postmenopausal females [69]. Increased bioavailable estrogen stimulated the proliferation of ER-positive and/or estrogen-dependent breast cancer [123]. Hyperinsulinemia in T2DM induced the expression and increased the binding capacity of ER [124, 125]. The activation of ER can also enhance insulin mitogenicity by promoting IRS-1 function and activating PI3K 
and Ras/MAPK signaling [126]. The inflammatory mediators, TNF $\alpha$ and IL-6, which are associated with insulin resistance in T2DM, enhanced estrogen production in both normal and breast cancer cells and could be expected to result in the development and proliferation of breast cancer cells [127].

3.2. Endometrial Cancer. Endometrial cancer is the most common gynecological cancer and is closely associated with endometrial hyperplasia, unopposed estrogen exposure, and genetic alterations $[128,129]$. This cancer has been associated strongly with T2DM in most epidemiological studies $[13,15$, $117,118,130-132]$. Many studies have suggested that T2DM and endometrial cancer share characteristics regarding the major modifiable determinates, such as low physical activity and obesity [133-135]. A meta-analysis of 16 studies (13 casecontrol and three cohort studies between 1956 and June 2005) indicated that T2DM had a significantly increased risk and comorbidity with endometrial cancer with a summary RR of 2.10 (95\% CI: 1.75-2.53). The risk was particularly strong among studies with age-adjusted estimates (RR 2.74; 95\% CI: 1.87-4.00) [13]. Also, a recent population-based and retrospective cohort study demonstrated that endometrial cancer and diabetes were strongly associated, with an HR of 1.81 (95\% CI: 1.37-2.41), and had an increased relationship, with an ageadjusted HR of 1.85 (95\% CI: 1.36-2.50) [15]. Although some studies have shown that endometrial cancer and diabetes had no significant statistical association with mortality [117], most studies have indicated that diabetes is associated with an increased risk of death from endometrial cancer; for example, a prospective study reported a multivariable-adjusted RR of 1.33 (95\% CI: 1.08-1.65) and an age-adjusted RR of $1.72(95 \%$ CI: 1.40-2.12) [3].

Similar to breast cancer cells, in vitro studies have shown that endometrial cancer cell lines increased proliferation by activation of insulin, IGF-1, and ovarian steroid hormone signaling pathways, such as estrogen and androgen signaling pathways [54]. Although endometrial cancer has no direct correlation with insulin or IGF levels, additional factors such as ovarian steroid hormones and/or inflammatory cytokines may make it difficult to confirm a single effect of insulin or IGF activation through insulin or IGF serum levels. Estrogen can activate IGF1R on endometrial cancer cells, thereby enhancing cellular proliferation through PI3K signaling, a link to IGF1R activation [136]. The androgen receptor (AR) activated by the binding of androgen could enhance the proliferation of endometrial cancer cells by the Notch signaling pathway [93]. C-reactive protein (CRP), which is an inflammatory biomarker induced by IL-6, was increased by insulin resistance and was associated with an increased risk of endometrial cancer in postmenopausal women [137]. Therefore, endometrial cancer may be associated with chronic inflammation in T2DM.

3.3. Ovarian Cancer. Although ovarian cancer is the ninth most common cancer and represents the fifth leading cause of death in women worldwide [138], studies concerning the relationship between ovarian cancer and T2DM are limited. One reason could be due to well-known and very important factors such as familial history, genetic mutations, menstrual cycles, and usage of oral contraceptives [139, 140]. However, some incidences in which the ovary displays insulin sensitivity and steroidogenesis induced by insulin and IGFs suggest that T2DM may be an important risk factor for ovarian cancer $[141,142]$. Although small-scale epidemiological studies have demonstrated inconsistent results regarding the relationship between ovarian cancer and T2DM, a recent meta-analysis of 19 studies (six case-case control, one nested case-control, and 12 cohort studies between 1976 and 2007) indicated that women with diabetes had an increased risk of ovarian cancer with a summary RR of 1.17 (95\% CI: 1.02-1.33) [3, 5, 117, 118, 143-146]. Many epidemiological studies have shown that ovarian cancer is associated with increased serum androgen levels and decreased serum progesterone levels rather than altered serum estrogen levels [79, 147]. These hormonal changes appear in diabetes and may be one reason for the increased risk of ovarian cancer in T2DM.

Although there is no experimental evidence for the positive association between insulin and ovarian cancer, some studies have shown that the increased serum levels of IGF-1, IGF-1R, and IGFBP-2 were associated positively in patients with ovarian cancer [55]. One study demonstrated that IGF-1 in human ovarian OVCAR-3 cells enhanced the expression of $\mathrm{KCl}$ cotransport (KCC) and was associated with proliferation and invasiveness of ovarian cancer cells [148]. Other studies have also shown that IGF-1 and IGFBP-2 in human ovarian cancer cell lines resulted in the induction of proliferation and invasion through phosphorylation of AKT and ERK1/2 [149, 150]. The significance of inflammation in ovarian carcinogenesis stems from the relationship between increased ovulation and ovarian cancer risk [151]. The role of androgen in stimulating the proliferation of ovarian cancer cells may also be associated with increased IL- 6 and decreased transforming growth factor beta (TGF $\beta)$, which were included in the proinflammatory network $[92,152]$.

\section{The Role of Diabetes Medications in Cancer Development in Women}

The potential effects of antidiabetic medications on cancer have sparked recent discussion and concern among the epidemiological and experimental studies related to the potential underlying mechanisms. In this section, we discuss the relationship between cancer risk and antidiabetic medication, including insulin and insulin analogs, metformin, and thiazolidinediones.

4.1. Insulin/Insulin Analogues. As noted above, because excessive insulin and IGF-1 signaling by hyperinsulinemia may be one of the most important causes of the development and proliferation of cancer, exogenous insulin is a suspected powerful carcinogenetic factor in diabetes patients. Increased circulating insulin levels over endogenous insulin secretion occur frequently with subcutaneous insulin injection, thereby making possible the association between insulin therapy and cancer [21, 153, 154]. Nevertheless, all patients with type 1 DM (T1DM) and approximately $40 \sim 80 \%$ of patients with 
T2DM are considered for insulin therapy to maintain proper glycemic control [155].

A significant number of epidemiological studies have suggested that insulin use and daily doses, particularly of the long-acting insulin analog glargine, may be responsible for the association with and strong increase in the risk of cancer [156-160]. A recent meta-analysis of 15 studies (five case-control and 10 cohort studies) demonstrated that insulin treatment was associated significantly with an increased risk of overall cancer with a summary RR of 1.39 (95\% CI: 1.14-1.70), particularly in case-control studies that evaluated TIDM, with a higher summary RR of 1.83 (95\% CI; 0.99-3.38) [161]. Some studies showed a strong relationship between insulin glargine and breast cancer, particularly in T2DM patients treated with insulin for more than 5 years $[162,163]$. Only a few studies with large-scale patient databases exist, such as the ORIGIN trial which enrolled 12,537 patients and followed them for 6.2 years (interquartile range, 5.86.7 years) and showed no statistically significant association between cancer risk and insulin glargine use; however, these results may be due to very well-controlled glucose levels, as well as the inclusion of prediabetic patients $[9,164]$. Therefore, optional selection between insulin treatment and proper glucose control may be needed for patients with diabetes, particularly T2DM.

4.2. Metformin. Metformin is an oral antidiabetic drug classified as an insulin sensitizer and is the most widely used drug, prescribed as the initial or in combination therapy, for T2DM [165]. Metformin reduces serum glucose and insulin levels in diabetic patients via improved insulin sensitivity, which reduces glucose production in the liver and increases glucose uptake in the muscles $[166,167]$. Another feature of metformin that attracts special attention is its anticancer effects supported by evidence from epidemiologic, in vitro, and in vivo model studies [3, 168-175].

In in vitro studies, metformin inhibits complex I of the mitochondrial respiratory chain, resulting in ATP/AMP imbalance, thereby activating AMP-activated protein kinase (AMPK) [176]. Activated AMPK inhibits mTOR signaling and interferes with the roles of cyclin D1 and p53. The latter two proteins not only alter glucose metabolism but also reduce cell proliferation through cell cycle interference [177$181]$.

The anticancer effects of metformin have been shown to reduce spontaneous mammary tumor development in rodent animal models $[182,183]$. However, some studies using mouse models found that metformin induced insulin resistance and hyperinsulinemia, which suggested that the anticancer effect of metformin may be mediated by reduced serum insulin levels [184]. In other words, the insulin-lowering effect of metformin was associated with its anticancer effect, thereby having less of an impact on cancer in patients with normal or lower insulin levels.

Most epidemiological studies have suggested that metformin used for T2DM reduces the risk, progression, and mortality of overall cancer [169, 171, 185-189]. Although those studies were limited in their assessment of a detailed relationship between metformin and specific cancer types, a recent meta-analysis of 28 studies showed that metformin has a significant inverse association with cancer mortality, including endometrial and ovarian cancers [187].

4.3. Thiazolidinediones. Thiazolidinediones (TZDs) are insulin-sensitizing antidiabetic drugs belonging to the peroxisome proliferator-activated receptor (PPAR) agonist class that induce the transcription of genes associated with glucose and lipid metabolism through activation of PPAR $\gamma$, a nuclear receptor, to reduce insulin resistance [190]. The effects of TZDs in reducing insulin resistance may be expected to result in anticancer activities similar to those of metformin. Some studies have indicated antiangiogenic and anti-inflammatory effects of TZDs, as well as anticancer effects, such as the inhibition of proliferation and induction of apoptosis and differentiation [191]. However, unlike metformin, the effects of TZDs are inconsistent between in vitro and in vivo studies and depend on parameters such as the animal model (rodent versus nonrodent and nonhuman primate versus human) and cancer type [192-197]. Some studies in rodents have suggested that TZDs can even potentiate tumorigenesis as multispecies and multisex carcinogens [192, 198-200].

Epidemiological studies evaluating the relationship between TZDs and cancer risk are limited and have shown inconsistent results [201-205]. One meta-analysis of randomized clinical trials concerning rosiglitazone and cancer risk indicated that rosiglitazone did not alter the risk of cancer, including breast and female genital tract cancers [206]. A recent meta-analysis indicated that pioglitazone, but not rosiglitazone, was associated significantly with a decreased risk of breast cancer (Mantel-Haenszel odds ratio (MH-OR): 0.28 [0.09-0.93]; $P=0.038$ ), but neither pioglitazone nor rosiglitazone altered the risk of uterine cancer (MH-OR: 0.77 [0.34-1.73]; $P=0.52$ ) [207].

\section{Conclusion}

The incidence and prevalence of gynecologic cancers are increased in patients with T2DM. Similar to other cancers, gynecologic cancers have several common mechanisms with T2DM, including increased insulin and IGF signaling and chronic inflammation. Unlike other cancers, dysregulation of ovarian steroid hormones is another commonly associated mechanism between T2DM and gynecologic cancer. Insulin resistance could induce or aggravate ovarian steroid hormone dysregulation and chronic inflammation in diabetic women. Most epidemiological studies have suggested that cancer in diabetic women can be modulated by insulin sensitizers such as metformin and TZDs. The management of insulin resistance is a main factor in controlling blood glucose and preventing cancer in female diabetic patients.

Thus, clinicians should recommend life-style changes such as weight-loss diets and exercise to overcome insulin resistance in women with T2DM. Additionally, clinicians should attend to and perform screening tests for gynecologic cancers according to currently established routines until screening protocols are developed for each specific gynecologic cancer in women with T2DM. 


\section{Conflict of Interests}

The authors declare that there is no conflict of interests regarding the publication of this paper.

\section{Acknowledgments}

The authors thank Amanda Sterling for paper preparation. This work was supported by the National Research Foundation of Korea Grant (NRF-2013R1A1A2004719) funded by the Korean Government (to Bon Jeong Ku), Grant NIH R01 HD057873, and American Cancer Society Research Grant RSG-12-084-01-TBG (to Jae-Wook Jeong).

\section{References}

[1] W. Rathmann, G. Giani, S. H. Wild et al., "Global prevalence of diabetes: estimates for the year 2000 and projections for 2030," Diabetes Care, vol. 27, no. 10, pp. 2568-2569, 2004.

[2] P. Zhang, X. Zhang, J. Brown et al., "Global healthcare expenditure on diabetes for 2010 and 2030," Diabetes Research and Clinical Practice, vol. 87, no. 3, pp. 293-301, 2030.

[3] P. T. Campbell, E. J. Jacobs, C. C. Newton, S. M. Gapstur, and A. V. Patel, "Diabetes and cause-specific mortality in a prospective cohort of one million U.S. adults," Diabetes Care, vol. 35, no. 9, pp. 1835-1844, 2012.

[4] S. R. Seshasai, S. Kaptoge, A. Thompson et al., "Diabetes mellitus, fasting glucose, and risk of cause-specific death," The New England Journal of Medicine, vol. 364, no. 9, pp. 829-841, 2011.

[5] S. S. Coughlin, E. E. Calle, L. R. Teras, J. Petrelli, and M. J. Thun, "Diabetes mellitus as a predictor of cancer mortality in a large cohort of US adults," American Journal of Epidemiology, vol. 159, no. 12, pp. 1160-1167, 2004.

[6] S. D. Nath, S. L. Habib, H. E. Abboud et al., "Fasting serum glucose level and cancer risk in Korean men and women," Journal of the American Medical Association, vol. 293, no. 18, pp. 2210-2211, 2005.

[7] G. Chodick, A. D. Heymann, L. Rosenmann et al., "Diabetes and risk of incident cancer: a large population-based cohort study in Israel," Cancer Causes and Control, vol. 21, no. 6, pp. 879-887, 2010.

[8] E. K. K. Lam, G. D. Batty, R. R. Huxley et al., "Associations of diabetes mellitus with site-specific cancer mortality in the AsiaPacific region," Annals of Oncology, vol. 22, no. 3, pp. 730-738, 2011.

[9] Y. Handelsman, D. Leroith, Z. T. Bloomgarden et al., "Diabetes and cancer-an AACE/ACE consensus statement," Endocrine Practice, vol. 19, no. 4, pp. 675-693, 2013.

[10] A. Czyzyk and Z. Szczepanik, "Diabetes mellitus and cancer," European Journal of Internal Medicine, vol. 11, no. 5, pp. 245$252,2000$.

[11] S. C. Larsson, C. S. Mantzoros, and A. Wolk, "Diabetes mellitus and risk of breast cancer: a meta-analysis," International Journal of Cancer, vol. 121, no. 4, pp. 856-862, 2007.

[12] S. C. Larsson, N. Orsini, and A. Wolk, "Diabetes mellitus and risk of colorectal cancer: a meta-analysis," Journal of the National Cancer Institute, vol. 97, no. 22, pp. 1679-1687, 2005.

[13] E. Friberg, N. Orsini, C. S. Mantzoros, and A. Wolk, "Diabetes mellitus and risk of endometrial cancer: a meta-analysis," Diabetologia, vol. 50, no. 7, pp. 1365-1374, 2007.
[14] E. M. Ko, P. Walter, L. Clark et al., "The complex triad of obesity, diabetes and race in Type I and II endometrial cancers: prevalence and prognostic significance," Gynecologic Oncology, vol. 133, no. 1, pp. 28-32, 2014.

[15] H.-F. Chen, M.-D. Liu, P. Chen et al., "Risks of breast and endometrial cancer in women with diabetes: a populationbased cohort study," PLoS ONE, vol. 8, no. 6, Article ID e67420, 2013.

[16] R. Huxley, A. Ansary-Moghaddam, A. Berrington de González, F. Barzi, and M. Woodward, "Type-II diabetes and pancreatic cancer: a meta-analysis of 36 studies," British Journal of Cancer, vol. 92, no. 11, pp. 2076-2083, 2005.

[17] H. B. El-Serag, H. Hampel, and F. Javadi, "The association between diabetes and hepatocellular carcinoma: a systematic review of epidemiologic evidence," Clinical Gastroenterology and Hepatology, vol. 4, no. 3, pp. 369-380, 2006.

[18] H. Fang, B. Yao, Y. Yan et al., "Diabetes mellitus increases the risk of bladder cancer: an updated meta-analysis of observational studies," Diabetes Technology and Therapeutics, vol. 15, no. 11, pp. 914-922, 2013.

[19] B. B. Barone, H.-C. Yeh, C. F. Snyder et al., "Long-term allcause mortality in cancer patients with preexisting diabetes mellitus: a systematic review and meta-analysis," The Journal of the American Medical Association, vol. 300, no. 23, pp. 27542764, 2008.

[20] R. Clarke, M. Shipley, S. Lewington et al., "Underestimation of risk associations due to regression dilution in long- term follow-up of prospective studies," The American Journal of Epidemiology, vol. 150, no. 4, pp. 341-353, 1999.

[21] S. L. Habib and M. Rojna, "Diabetes and risk of cancer," ISRN Oncology, vol. 2013, Article ID 583786, 16 pages, 2013.

[22] F. Ikeda, Y. Doi, K. Yonemoto et al., "Hyperglycemia increases risk of gastric cancer posed by Helicobacter pylori infection: a population-based cohort study," Gastroenterology, vol. 136, no. 4, pp. 1234-1241, 2009.

[23] T. N. Le, J. E. Nestler, J. F. Strauss, and E. P. Wickham, "Sex hormone-binding globulin and type 2 diabetes mellitus," Trends in Endocrinology \& Metabolism, vol. 23, no. 1, pp. 32-40, 2012.

[24] S. K. Pal and A. Hurria, "Impact of age, sex, and comorbidity on cancer therapy and disease progression," Journal of Clinical Oncology, vol. 28, no. 26, pp. 4086-4093, 2010.

[25] J. H. Koo and R. W. L. Leong, "Sex differences in epidemiological, clinical and pathological characteristics of colorectal cancer," Journal of Gastroenterology and Hepatology, vol. 25, no. 1, pp. 33-42, 2010.

[26] M. Pollak, "Insulin and insulin-like growth factor signalling in neoplasia," Nature Reviews Cancer, vol. 8, no. 12, pp. 915-928, 2008.

[27] J. A. Cooper, D. F. Bowen-Pope, E. Raines, R. Ross, and T. Hunter, "Similar effects of platelet-derived growth factor and epidermal growth factor on the phosphorylation of tyrosine in cellular proteins," Cell, vol. 31, no. 1, pp. 263-273, 1982.

[28] N. Chegini, M. J. Rossi, and B. J. Masterson, "Platelet-derived growth factor (PDGF), epidermal growth factor (EGF), and EGF and PDGF $\beta$-receptors in human endometrial tissue: localization and in vitro action," Endocrinology, vol. 130, no. 4, pp. 2373-2385, 1992.

[29] Z. Laron, "IGF-1 and insulin as growth hormones," Novartis Foundation Symposium, vol. 262, pp. 56-83, 265-268, 2004.

[30] V. Pezzino, A. Costantino, P. Russo, D. Gullo, and V. Papa, "Insulin receptor content in tissues of normal and diabetic 
rats measured by radioimunoassay," Journal of Endocrinological Investigation, vol. 19, no. 9, pp. 593-597, 1996.

[31] C. Hernández-Sánchez, A. Mansilla, F. De Pablo, and R. Zardoya, "Evolution of the insulin receptor family and receptor isoform expression in vertebrates," Molecular Biology and Evolution, vol. 25, no. 6, pp. 1043-1053, 2008.

[32] P. de Meyts, "Insulin and its receptor: structure, function and evolution," BioEssays, vol. 26, no. 12, pp. 1351-1362, 2004.

[33] E. S. Schernhammer, J. M. Holly, D. J. Hunter, M. N. Pollak, and S. E. Hankinson, "Insulin-like growth factor-I, its binding proteins (IGFBP-1 and IGFBP-3), and growth hormone and breast cancer risk in The Nurses Health Study II," EndocrineRelated Cancer, vol. 13, no. 2, pp. 583-592, 2006.

[34] A. Belfiore, F. Frasca, G. Pandini, L. Sciacca, and R. Vigneri, "Insulin receptor isoforms and insulin receptor/insulin-like growth factor receptor hybrids in physiology and disease," Endocrine Reviews, vol. 30, no. 6, pp. 586-623, 2009.

[35] S. Benyoucef, K. H. Surinya, D. Hadaschik, and K. Siddle, "Characterization of insulin/IGF hybrid receptors: contributions of the insulin receptor L2 and Fn1 domains and the alternatively spliced exon 11 sequence to ligand binding and receptor activation," Biochemical Journal, vol. 403, no. 3, pp. 603-613, 2007.

[36] D. LeRoith, "Insulin-like growth factor I receptor signalingoverlapping or redundant pathways?" Endocrinology, vol. 141, no. 4, pp. 1287-1288, 2000.

[37] P. J. Jenkins, "Cancers associated with acromegaly," Neuroendocrinology, vol. 83, no. 3-4, pp. 218-223, 2006.

[38] E. E. Calle, C. Rodriguez, K. Walker-Thurmond, and M. J. Thun, "Overweight, obesity, and mortality from cancer in a prospectively studied cohort of U.S. Adults," The New England Journal of Medicine, vol. 348, no. 17, pp. 1625-1638, 2003.

[39] D. L. Roberts, C. Dive, and A. G. Renehan, "Biological mechanisms linking obesity and cancer risk: new perspectives," Annual Review of Medicine, vol. 61, pp. 301-316, 2010.

[40] D. H. Cohen and D. LeRoith, "Obesity, type 2 diabetes, and cancer: the insulin and IGF connection," Endocrine-Related Cancer, vol. 19, no. 5, pp. F27-F45, 2012.

[41] Y. Gu, C. Wang, Y. Zheng et al., "Cancer incidence and mortality in patients with type 2 diabetes treated with human insulin: a cohort study in Shanghai," PLoS ONE, vol. 8, no. 1, Article ID e53411, 2013.

[42] J. Ma, H. Li, E. Giovannucci et al., "Prediagnostic body-mass index, plasma C-peptide concentration, and prostate cancerspecific mortality in men with prostate cancer: a long-term survival analysis," The Lancet Oncology, vol. 9, no. 11, pp. 10391047, 2008.

[43] J. Ma, E. Giovannucci, M. Pollak et al., "A prospective study of plasma C-peptide and colorectal cancer risk in men," Journal of the National Cancer Institute, vol. 96, no. 7, pp. 546-553, 2004.

[44] R. Dankner, M. H. Shanik, L. Keinan-Boker, C. Cohen, and A. Chetrit, "Effect of elevated basal insulin on cancer incidence and mortality in cancer incident patients: the Israel GOH 29year follow-up study," Diabetes Care, vol. 35, no. 7, pp. 1538-1543, 2012.

[45] M. Lippman, G. Bolan, and K. Huff, "The effects of estrogens and antiestrogens on hormone responsive human breast cancer in long term tissue culture," Cancer Research, vol. 36, no. 12, pp. 4595-4601, 1976.

[46] C. K. Osborne, G. Bolan, M. E. Monaco, and M. E. Lippman, "Hormone responsive human breast cancer in long term tissue culture: effect of insulin," Proceedings of the National Academy of Sciences of the United States of America, vol. 73, no. 12, pp. 4536-4540, 1976.

[47] H. Zhang, D. H. Fagan, X. Zeng, K. T. Freeman, D. Sachdev, and D. Yee, "Inhibition of cancer cell proliferation and metastasis by insulin receptor downregulation," Oncogene, vol. 29, no. 17, pp. 2517-2527, 2010.

[48] J. C. Heuson and N. Legros, "Influence of insulin deprivation on growth of the 7,12-dimethylbenz(a)anthracene-induced mammary carcinoma in rats subjected to alloxan diabetes and food restriction.," Cancer Research, vol. 32, no. 2, pp. 226-232, 1972.

[49] S. M. Firth and R. C. Baxter, "Cellular actions of the insulin-like growth factor binding proteins," Endocrine Reviews, vol. 23, no. 6, pp. 824-854, 2002.

[50] V. A. Ezzat, E. R. Duncan, S. B. Wheatcroft, and M. T. Kearney, "The role of IGF-I and its binding proteins in the development of type 2 diabetes and cardiovascular disease," Diabetes, Obesity and Metabolism, vol. 10, no. 3, pp. 198-211, 2008.

[51] S. Söderberg, B. Ahrén, M. Eliasson, B. Dinesen, K. Brismar, and T. Olsson, "Circulating IGF binding protein-1 is inversely associated with leptin in non-obese men and obese postmenopausal women," European Journal of Endocrinology, vol. 144, no. 3, pp. 283-290, 2001.

[52] A. López-Bermejo, J. Khosravi, J. M. Fernández-Real et al., "Insulin resistance is associated with increased serum concentration of IGF-binding protein-related protein 1 (IGFBPrP1/MAC25)," Diabetes, vol. 55, no. 8, pp. 2333-2339, 2006.

[53] D. P. Rose and L. Vona-Davis, "The cellular and molecular mechanisms by which insulin influences breast cancer risk and progression," Endocrine-Related Cancer, vol. 19, no. 6, pp. R225R241, 2012.

[54] N. Mu, Y. Zhu, Y. Wang, H. Zhang, and F. Xue, "Insulin resistance: a significant risk factor of endometrial cancer," Gynecologic Oncology, vol. 125, no. 3, pp. 751-757, 2012.

[55] M. C. Beauchamp, A. Yasmeen, A. Knafo, and W. H. Gotlieb, "Targeting insulin and insulin-like growth factor pathways in epithelial ovarian cancer," Journal of Oncology, vol. 2010, Article ID 257058, 11 pages, 2010.

[56] M. Pollak, "The insulin and insulin-like growth factor receptor family in neoplasia: an update," Nature Reviews Cancer, vol. 12, no. 3, pp. 159-169, 2012.

[57] P. K. Siiteri, "Steroid hormones and endometrial cancer," Cancer Research, vol. 38, no. 11, part 2, pp. 4360-4366, 1978.

[58] T. J. A. Key and M. C. Pike, "The dose-effect relationship between "unopposed" oestrogens and endometrial mitotic rate: its central role in explaining and predicting endometrial cancer risk," British Journal of Cancer, vol. 57, no. 2, pp. 205-212, 1988.

[59] A. Lukanova and R. Kaaks, "Endogenous hormones and ovarian cancer: epidemiology and current hypotheses," Cancer Epidemiology Biomarkers and Prevention, vol. 14, no. 1, pp. 98-107, 2005.

[60] A. Ferenczy, G. Bertrand, and M. M. Gelfand, "Proliferation kinetics of human endometrium during the normal menstrual cycle," American Journal of Obstetrics \& Gynecology, vol. 133, no. 8, pp. 859-867, 1979.

[61] C. L. Wilson, A. H. Sims, A. Howell, C. J. Miller, and R. B. Clarke, "Effects of oestrogen on gene expression in epithelium and stroma of normal human breast tissue," Endocrine-Related Cancer, vol. 13, no. 2, pp. 617-628, 2006.

[62] J. Stingl, "Estrogen and progesterone in normal mammary gland development and in cancer," Hormones and Cancer, vol. 2, no. 2, pp. 85-90, 2011. 
[63] R. F. Spengler, E. A. Clarke, C. A. Woolever, A. M. Newman, and R. W. Osborn, "Exogenous estrogens and endometrial cancer: a case-control study and assessment of potential biases," American Journal of Epidemiology, vol. 114, no. 4, pp. 497-506, 1981.

[64] E. J. Crosbie, M. Zwahlen, H. C. Kitchener, M. Egger, and A. G. Renehan, "Body mass index, hormone replacement therapy, and endometrial cancer risk: a meta-analysis," Cancer Epidemiology Biomarkers and Prevention, vol. 19, no. 12, pp. 3119-3130, 2010.

[65] K. K. Steinberg, S. B. Thacker, S. J. Smith et al., "A meta-analysis of the effect of estrogen replacement therapy on the risk of breast cancer," The Journal of the American Medical Association, vol. 265, no. 15, pp. 1985-1990, 1991.

[66] C. Magnusson, I. Persson, and H.-O. Adami, "More about: effect of hormone replacement therapy on breast cancer risk: estrogen versus estrogen plus progestin," Journal of the National Cancer Institute, vol. 92, no. 14, pp. 1183-1184, 2000.

[67] P. G. Toniolo, M. Levitz, A. Zeleniuch-Jacquotte et al., "A prospective study of endogenous estrogens and breast cancer in postmenopausal women," Journal of the National Cancer Institute, vol. 87, no. 3, pp. 190-197, 1995.

[68] A. Akhmedkhanov, A. Zeleniuch-Jacquotte, and P. Toniolo, "Role of exogenous and endogenous hormones in endometrial cancer: review of the evidence and research perspectives," Annals of the New York Academy of Sciences, vol. 943, pp. 296$315,2001$.

[69] C. M. Friedenreich, "Review of anthropometric factors and breast cancer risk," European Journal of Cancer Prevention, vol. 10, no. 1, pp. 15-32, 2001.

[70] S. C. Sommers, A. T. Hertig, and H. Bengloff, "Genesis of endometrial carcinoma; cases 19 to 35 years old," Cancer, vol. 2, no. 6, pp. 957-963, 1949.

[71] E. Ron, B. Lunenfeld, J. Menczer et al., "Cancer incidence in a cohort of infertile women," American Journal of Epidemiology, vol. 125, no. 5, pp. 780-790, 1987.

[72] S. Wild, T. Pierpoint, H. Jacobs, and P. McKeigue, "Long-term consequences of polycystic ovary syndrome: results of a 31 year follow-up study," Human Fertility, vol. 3, no. 2, pp. 101-105, 2000.

[73] C. B. Coulam, J. F. Annegers, and J. S. Kranz, "Chronic anovulation syndrome and associated neoplasia," Obstetrics and Gynecology, vol. 61, no. 4, pp. 403-407, 1983.

[74] A. Daniilidis and K. Dinas, "Long term health consequences of polycystic ovarian syndrome: a review analysis," Hippokratia, vol. 13, no. 2, pp. 90-92, 2009.

[75] N. Potischman, R. N. Hoover, L. A. Brinton et al., "Casecontrol study of endogenous steroid hormones and endometrial cancer," Journal of the National Cancer Institute, vol. 88, no. 16, pp. 1127-1135, 1996.

[76] B. Pettersson, R. Bergstrom, and E. D. B. Johansson, "Serum estrogens and androgens in women with endometrial carcinoma," Gynecologic Oncology, vol. 25, no. 2, pp. 223-233, 1986.

[77] H. C. J. Nyholm, A. L. Nielsen, J. Lyndrup, A. Dreisler, C. Hagen, and E. Haug, "Plasma oestrogens in postmenopausal women with endometrial cancer," British Journal of Obstetrics and Gynaecology, vol. 100, no. 12, pp. 1115-1119, 1993.

[78] J. A. Nisker, G. L. Hammond, B. J. Davidson et al., "Serum sex hormone-binding globulin capacity and the percentage of free estradiol in postmenopausal women with and without endometrial carcinoma. A new biochemical basis for the association between obesity and endometrial carcinoma," American Journal of Obstetrics and Gynecology, vol. 138, no. 6, pp. 637-642, 1980.
[79] J. M. Schildkraut, P. J. Schwingl, E. Bastos, A. Evanoff, C. Hughes, and J. P. Curtin, "Epithelial ovarian cancer risk among women with polycystic ovary syndrome," Obstetrics \& Gynecology, vol. 88, no. 4, part 1, pp. 554-559, 1996.

[80] E. G. Silva, C. Tornos, H. A. Fritsche Jr. et al., “The induction of benign epithelial neoplasms of the ovaries of guinea pigs by testosterone stimulation: a potential animal model," Modern Pathology, vol. 10, no. 9, pp. 879-883, 1997.

[81] I. Wiegratz, C. Jung-Hoffmann, and H. Kuhl, "Effect of two oral contraceptives containing ethinylestradiol and gestodene or norgestimate upon androgen parameters and serum binding proteins," Contraception, vol. 51, no. 6, pp. 341-346, 1995.

[82] N. Fortunati, M. G. Catalano, G. Boccuzzi, and R. Frairia, "Sex Hormone-Binding Globulin (SHBG), estradiol and breast cancer," Molecular and Cellular Endocrinology, vol. 316, no. 1, pp. 86-92, 2010.

[83] G. N. Armaiz-Pena, L. S. Mangala, W. A. Spannuth et al., "Estrous cycle modulates ovarian carcinoma growth," Clinical Cancer Research, vol. 15, no. 9, pp. 2971-2978, 2009.

[84] C.-H. Chien, F.-F. Wang, and T. C. Hamilton, “Transcriptional activation of $c-m y c$ proto-oncogene by estrogen in human ovarian cancer cells," Molecular and Cellular Endocrinology, vol. 99, no. 1, pp. 11-19, 1994.

[85] A. V. Lee, J. G. Jackson, J. L. Gooch et al., "Enhancement of insulin-like growth factor signaling in human breast cancer: estrogen regulation of insulin receptor substrate-1 expression in vitro and in vivo," Molecular Endocrinology, vol. 13, no. 5, pp. 787-796, 1999.

[86] L. C. Giudice, G. Lamson, R. G. Rosenfeld, and J. C. Irwin, "Insulin-like growth factor-II (IGF-II) and IGF binding proteins in human endometrium," Annals of the New York Academy of Sciences, vol. 626, pp. 295-307, 1991.

[87] L. J. Murphy and A. Ghahary, "Uterine insulin-like growth factor-1: regulation of expression and its role in estrogeninduced uterine proliferation," Endocrine Reviews, vol. 11, no. 3, pp. 443-453, 1990.

[88] V. Bartella, P. de Marco, R. Malaguarnera, A. Belfiore, and M. Maggiolini, "New advances on the functional cross-talk between insulin-like growth factor-I and estrogen signaling in cancer," Cellular Signalling, vol. 24, no. 8, pp. 1515-1521, 2012.

[89] D. H. Fagan, R. R. Uselman, D. Sachdev, and D. Yee, "Acquired resistance to tamoxifen is associated with loss of the type I insulin-like growth factor receptor: implications for breast cancer treatment," Cancer Research, vol. 72, no. 13, pp. 33723380, 2012.

[90] T. Winder, G. Giamas, P. M. Wilson et al., "Insulin-like growth factor receptor polymorphism defines clinical outcome in estrogen receptor-positive breast cancer patients treated with tamoxifen," Pharmacogenomics Journal, vol. 14, no. 1, pp. 28-34, 2014.

[91] S. Periyasamy-Thandavan, S. Takhar, A. Singer et al., "Insulinlike growth factor 1 attenuates antiestrogen- and antiprogestininduced apoptosis in $\mathrm{ER}^{+}$breast cancer cells by MEK1 regulation of the BH3-only pro-apoptotic protein Bim," Breast Cancer Research, vol. 14, no. 2, p. R52, 2012.

[92] V. Syed, G. Ulinski, S. C. Mok, and S.-M. Ho, "Reproductive hormone-induced, STAT3-mediated interleukin 6 action in normal and malignant human ovarian surface epithelial cells," Journal of the National Cancer Institute, vol. 94, no. 8, pp. 617629, 2002. 
[93] M. Qiu, W. Bao, J. Wang et al., "FOXA1 promotes tumor cell proliferation through AR involving the Notch pathway in endometrial cancer," BMC Cancer, vol. 14, no. 1, article 78, 2014.

[94] L. E. Underwood, J.-P. Thissen, S. Lemozy, J.-M. Ketelslegers, and D. R. Clemmons, "Hormonal and nutritional regulation of IGF-I and its binding proteins," Hormone Research, vol. 42, no. 4-5, pp. 145-151, 1994.

[95] J.-P. Thissen, J.-M. Ketelslegers, and L. E. Underwood, "Nutritional regulation of the insulin-like growth factors," Endocrine Reviews, vol. 15, no. 1, pp. 80-101, 1994.

[96] R. Pasquali, V. Vicennati, D. Bertazzo et al., "Determinants of sex hormone-binding globulin blood concentrations in premenopausal and postmenopausal women with different estrogen status," Metabolism: Clinical and Experimental, vol. 46, no. 1, pp. 5-9, 1997.

[97] D. P. Rose, D. Komninou, and G. D. Stephenson, "Obesity, adipocytokines, and insulin resistance in breast cancer," Obesity Reviews, vol. 5, no. 3, pp. 153-165, 2004.

[98] D. Pardoll, "Does the immune system see tumors as foreign or self?" Annual Review of Immunology, vol. 21, pp. 807-839, 2003.

[99] M. Philip, D. A. Rowley, and H. Schreiber, "Inflammation as a tumor promoter in cancer induction," Seminars in Cancer Biology, vol. 14, no. 6, pp. 433-439, 2004.

[100] J.-L. Luo, S. Maeda, L.-C. Hsu, H. Yagita, and M. Karin, "Inhibition of NF- $\kappa \mathrm{B}$ in cancer cells converts inflammationinduced tumor growth mediated by TNF $\alpha$ to TRAIL-mediated tumor regression," Cancer Cell, vol. 6, no. 3, pp. 297-305, 2004.

[101] M. Karin and F. R. Greten, "NF- $\kappa$ B: linking inflammation and immunity to cancer development and progression," Nature Reviews Immunology, vol. 5, no. 10, pp. 749-759, 2005.

[102] K. Esposito, P. Chiodini, A. Colao, A. Lenzi, and D. Giugliano, "Metabolic syndrome and risk of cancer: a systematic review and meta-analysis," Diabetes Care, vol. 35, no. 11, pp. 2402-2411, 2012.

[103] P. Pothiwala, S. K. Jain, and S. Yaturu, "Metabolic syndrome and cancer," Metabolic Syndrome and Related Disorders, vol. 7, no. 4, pp. 279-287, 2009.

[104] K. Garber, "Aspirin for cancer chemoprevention: still a headache?" Journal of the National Cancer Institute, vol. 96, no. 4, pp. 252-253, 2004.

[105] R. B. Ness and C. Cottreau, "Possible role of ovarian epithelial inflammation in ovarian cancer," Journal of the National Cancer Institute, vol. 91, no. 17, pp. 1459-1467, 1999.

[106] D. K. Biswas, Q. Shi, S. Baily et al., "NF-kappa B activation in human breast cancer specimens and its role in cell proliferation and apoptosis," Proceedings of the National Academy of Sciences of the United States of America, vol. 101, no. 27, pp. 10137-10142, 2004.

[107] L. A. deGraffenried, B. Chandrasekar, W. E. Friedrichs et al., "NF- $\kappa \mathrm{B}$ inhibition markedly enhances sensitivity of resistant breast cancer tumor cells to tamoxifen," Annals of Oncology, vol. 15, no. 6, pp. 885-890, 2004.

[108] A. E. Wallace, D. A. Gibson, P. T. K. Saunders, and H. N. Jabbour, "Inflammatory events in endometrial adenocarcinoma," Journal of Endocrinology, vol. 206, no. 2, pp. 141-157, 2010.

[109] A. B. Alvero, "Recent insights into the role of NF- $\kappa$ B in ovarian carcinogenesis," Genome Medicine, vol. 2, no. 8, article 56, 2010.

[110] C. de Luca and J. M. Olefsky, "Inflammation and insulin resistance," FEBS Letters, vol. 582, no. 1, pp. 97-105, 2008.

[111] M. Y. Donath and S. E. Shoelson, "Type 2 diabetes as an inflammatory disease," Nature Reviews Immunology, vol. 11, no. 2, pp. 98-107, 2011.
[112] K. H. Seo, H.-S. Lee, B. Jung et al., "Estrogen enhances angiogenesis through a pathway involving platelet-activating factor-mediated nuclear factor- $\kappa \mathrm{B}$ activation," Cancer Research, vol. 64, no. 18, pp. 6482-6488, 2004.

[113] F. Modugno, R. B. Ness, C. Chen, and N. S. Weiss, "Inflammation and endometrial cancer: a hypothesis," Cancer Epidemiology Biomarkers and Prevention, vol. 14, no. 12, pp. 2840-2847, 2005.

[114] C. la Vecchia, S. H. Giordano, G. N. Hortobagyi, and B. Chabner, "Overweight, obesity, diabetes, and risk of breast cancer: interlocking pieces of the puzzle," Oncologist, vol. 16, no. 6, pp. 726-729, 2011.

[115] K. B. Michels, C. G. Solomon, F. B. Hu et al., “Type 2 diabetes and subsequent incidence of breast cancer in the nurses' health study," Diabetes Care, vol. 26, no. 6, pp. 1752-1758, 2003.

[116] L. L. Lipscombe, P. J. Goodwin, B. Zinman, J. R. McLaughlin, and J. E. Hux, "The impact of diabetes on survival following breast cancer," Breast Cancer Research and Treatment, vol. 109, no. 2, pp. 389-395, 2008.

[117] C. J. Currie, C. D. Poole, S. Jenkins-Jones, E. A. M. Gale, J. A. Johnson, and C. L. Morgan, "Mortality after incident cancer in people with and without type 2 diabetes: impact of metformin on survival," Diabetes Care, vol. 35, no. 2, pp. 299-304, 2012.

[118] J.-Y. Chen, W.-K. Chiou, W.-Y. Chou, and J.-D. Lin, “The impact of type 2 diabetes mellitus on mortality in hospitalized female cancer patients in Taiwan," Asia-Pacific Journal of Clinical Oncology, 2013.

[119] S. Liao, J. Li, W. Wei et al., "Association between diabetes mellitus and breast cancer risk: a meta-analysis of the literature," Asian Pacific Journal of Cancer Prevention, vol. 12, no. 4, pp. 1061-1065, 2011.

[120] L. Sciacca, A. Costantino, G. Pandini et al., "Insulin receptor activation by IGF-II in breast cancers: evidence for a new autocrine/paracrine mechanism," Oncogene, vol. 18, no. 15, pp. 2471-2479, 1999.

[121] R. Novosyadlyy, D. E. Lann, A. Vijayakumar et al., "Insulinmediated acceleration of breast cancer development and progression in a nonobese model of type 2 diabetes," Cancer Research, vol. 70, no. 2, pp. 741-751, 2010.

[122] H. Nyholm, H. Djursing, C. Hagen, T. Agner, P. Bennett, and B. Svenstrup, "Androgens and estrogens in postmenopausal insulin-treated diabetic women," The Journal of Clinical Endocrinology and Metabolism, vol. 69, no. 5, pp. 946949, 1989.

[123] L. Vona-Davis and D. P. Rose, "Type 2 diabetes and obesity metabolic interactions: common factors for breast cancer risk and novel approaches to prevention and therapy," Current Diabetes Reviews, vol. 8, no. 2, pp. 116-130, 2012.

[124] B. S. Katzenellenbogen and M. J. Norman, "Multihormonal regulation of the progesterone receptor in MCF-7 human breast cancer cells: Interrelationships among insulin/insulinlike growth factor-I, serum, and estrogen," Endocrinology, vol. 126, no. 2, pp. 891-898, 1990.

[125] M. L. Panno, M. Salerno, V. Pezzi et al., "Effect of oestradiol and insulin on the proliferative pattern and on oestrogen and progesterone receptor contents in MCF-7 cells," Journal of Cancer Research and Clinical Oncology, vol. 122, no. 12, pp. 745749, 1996.

[126] L. Mauro, M. Salerno, M. L. Panno et al., "Estradiol increases IRS-1 gene expression and insulin signaling in breast cancer cells," Biochemical and Biophysical Research Communications, vol. 288 , no. 3, pp. 685-689, 2001. 
[127] A. Purohit, S. P. Newman, and M. J. Reed, "The role of cytokines in regulating estrogen synthesis: implications for the etiology of breast cancer," Breast Cancer Research, vol. 4, no. 2, pp. 65-69, 2002.

[128] A. Di Cristofano and L. H. Ellenson, "Endometrial carcinoma," Annual Review of Pathology, vol. 2, pp. 57-85, 2007.

[129] S. S. Jick, A. M. Walker, and H. Jick, "Estrogens, progesterone, and endometrial cancer," Epidemiology, vol. 4, no. 1, pp. 20-24, 1993.

[130] K. E. Anderson, E. Anderson, P. J. Mink et al., "Diabetes and endometrial cancer in the Iowa Women's Health Study," Cancer Epidemiology Biomarkers and Prevention, vol. 10, no. 6, pp. 611616, 2001.

[131] Y. Zhang, Z. Liu, X. Yu et al., "The association between metabolic abnormality and endometrial cancer: a large casecontrol study in China," Gynecologic Oncology, vol. 117, no. 1, pp. 41-46, 2010.

[132] E. Friberg, C. S. Mantzoros, and A. Wolk, "Diabetes and risk of endometrial cancer: a population-based prospective cohort study," Cancer Epidemiology Biomarkers and Prevention, vol. 16, no. 2, pp. 276-280, 2007.

[133] H. Vainio, R. Kaaks, and F. Bianchini, "Weight control and physical activity in cancer prevention: international evaluation of the evidence," European Journal of Cancer Prevention, vol. 11, supplement 2, pp. S94-S100, 2002.

[134] L. J. Schouten, R. A. Goldbohm, and P. A. van den Brandt, "Anthropometry, physical activity, and endometrial cancer risk: results from the Netherlands Cohort Study," Journal of the National Cancer Institute, vol. 96, no. 21, pp. 1635-1638, 2004.

[135] S. C. Modesitt and J. R. Van Nagell Jr., "The impact of obesity on the incidence and treatment of gynecologic cancers: a review," Obstetrical and Gynecological Survey, vol. 60, no. 10, pp. 683692, 2005.

[136] I. Bruchim, R. Sarfstein, and H. Werner, "The IGF hormonal network in endometrial cancer: functions, regulation, and targeting approaches," Frontiers in Endocrinology, vol. 5, p. 76, 2014.

[137] T. Wang, T. E. Rohan, M. J. Gunter et al., "A prospective study of inflammation markers and endometrial cancer risk in postmenopausal hormone nonusers," Cancer Epidemiology Biomarkers and Prevention, vol. 20, no. 5, pp. 971-977, 2011.

[138] R. Siegel, D. Naishadham, and A. Jemal, "Cancer statistics, 2012," CA: A Cancer Journal for Clinicians, vol. 62, no. 1, pp. 10-29, 2012.

[139] B. T. Hennessy, R. L. Coleman, and M. Markman, "Ovarian cancer," The Lancet, vol. 374, no. 9698, pp. 1371-1382, 2009.

[140] V. Beral, R. Doll, C. Hermon et al., "Ovarian cancer and oral contraceptives: collaborative reanalysis of data from 45 epidemiological studies including 23257 women with ovarian cancer and 87303 controls," The Lancet, vol. 371, no. 9609, pp. 303-314, 2008.

[141] L. Poretsky and M. F. Kalin, "The gonadotropic function of insulin.," Endocrine Reviews, vol. 8, no. 2, pp. 132-141, 1987.

[142] R. J. Chang, R. M. Nakamura, H. L. Judd, and S. A. Kaplan, "Insulin resistance in nonobese patients with polycystic ovarian disease," Journal of Clinical Endocrinology and Metabolism, vol. 57, no. 2, pp. 356-359, 1983.

[143] A. I. Adler, N. S. Weiss, M. L. Kamb, and J. L. Lyon, "Is diabetes mellitus a risk factor for ovarian cancer? A case-control study in Utah and Washington (United States)," Cancer Causes and Control, vol. 7, no. 4, pp. 475-478, 1996.
[144] J.-Y. Lee, I. Jeon, J. W. Kim, Y.-S. Song, J.-M. Yoon, and S. M. Park, "Diabetes mellitus and ovarian cancer risk: a systematic review and meta-analysis of observational studies," International Journal of Gynecological Cancer, vol. 23, no. 3, pp. 402-412, 2013.

[145] L. Wideroff, G. Gridley, L. Mellemkjaer et al., "Cancer incidence in a population-based cohort of patients hospitalized with diabetes mellitus in denmark," Journal of the National Cancer Institute, vol. 89, no. 18, pp. 1360-1365, 1997.

[146] S.-F. Lo, S.-N. Chang, C.-H. Muo et al., "Modest increase in risk of specific types of cancer types in type 2 diabetes mellitus patients," International Journal of Cancer, vol. 132, no. 1, pp. 182188, 2013.

[147] H. A. Risch, "Hormonal etiology of epithelial ovarian cancer, with a hypothesis concerning the role of androgens and progesterone," Journal of the National Cancer Institute, vol. 90, no. 23, pp. 1774-1786, 1998.

[148] M.-R. Shen, A.-C. Lin, Y.-M. Hsu et al., "Insulin-like growth factor 1 stimulates $\mathrm{KCl}$ cotransport, which is necessary for invasion and proliferation of cervical cancer and ovarian cancer cells," The Journal of Biological Chemistry, vol. 279, no. 38, pp. 40017-40025, 2004.

[149] Y. Tanaka, H. Kobayashi, M. Suzuki, Y. Hirashima, N. Kanayama, and T. Terao, "Genetic downregulation of pregnancy-associated plasma protein-A (PAPP-A) by bikunin reduces IGF-I-dependent Akt and ERK1/2 activation and subsequently reduces ovarian cancer cell growth, invasion and metastasis," International Journal of Cancer, vol. 109, no. 3, pp. 336-347, 2004

[150] E. J. Lee, C. Mircean, I. Shmulevich et al., "Insulin-like growth factor binding protein 2 promotes ovarian cancer cell invasion," Molecular Cancer, vol. 4, article 7, 2005.

[151] T. V. Clendenen, E. Lundin, A. Zeleniuch-Jacquotte et al., "Circulating inflammation markers and risk of epithelial ovarian cancer," Cancer Epidemiology Biomarkers and Prevention, vol. 20, no. 5, pp. 799-810, 2011.

[152] A. Evangelou, S. K. Jindal, T. J. Brown, and M. Letarte, "Down-regulation of transforming growth factor $\beta$ receptors by androgen in ovarian cancer cells," Cancer Research, vol. 60, no. 4, pp. 929-935, 2000.

[153] E. Giovannucci, D. M. Harlan, M. C. Archer et al., "Diabetes and cancer: a consensus report," CA: A Cancer Journal for Clinicians, vol. 60, no. 4, pp. 207-221, 2010.

[154] L. G. Hemkens, R. Bender, U. Grouven, and P. T. Sawicki, "Insulin glargine and cancer," The Lancet, vol. 374, no. 9703, pp. 1743-1744, 2009.

[155] S. Jabbour, "Primary care physicians and insulin initiation: multiple barriers, lack of knowledge or both?" International Journal of Clinical Practice, vol. 62, no. 6, pp. 845-847, 2008.

[156] C. J. Currie, C. D. Poole, and E. A. M. Gale, "The influence of glucose-lowering therapies on cancer risk in type 2 diabetes," Diabetologia, vol. 52, no. 9, pp. 1766-1777, 2009.

[157] J. M. Jonasson, R. Ljung, M. Talbäck, B. Haglund, S. Gudbjörnsdòttir, and G. Steineck, "Insulin glargine use and short-term incidence of malignancies-a population-based follow-up study in Sweden," Diabetologia, vol. 52, no. 9, pp. 1745-1754, 2009.

[158] H. M. Colhoun, "Use of insulin glargine and cancer incidence in Scotland: a study from the Scottish Diabetes Research Network Epidemiology Group," Diabetologia, vol. 52, no. 9, pp. 1755-1765, 2009. 
[159] L. G. Hemkens, U. Grouven, R. Bender et al., "Risk of malignancies in patients with diabetes treated with human insulin or insulin analogues: a cohort study," Diabetologia, vol. 52, no. 9, pp. 1732-1744, 2009.

[160] S. J. Pocock and L. Smeeth, "Insulin glargine and malignancy: an unwarranted alarm," The Lancet, vol. 374, no. 9689, pp. 511513, 2009.

[161] M. Janghorbani, M. Dehghani, and M. Salehi-Marzijarani, "Systematic review and meta-analysis of insulin therapy and risk of cancer," Hormones and Cancer, vol. 3, no. 4, pp. 137-146, 2012.

[162] R. Ljung, M. Talbäck, B. Haglund, J. M. Jonasson, S. Gudbjörnsdòttir, and G. Steineck, "Insulin glargine use and short-term incidence of breast cancer a four-year populationbased observation," Acta Oncologica, vol. 51, no. 3, pp. 400-402, 2012.

[163] S. Suissa, L. Azoulay, S. Dell'Aniello, M. Evans, J. Vora, and M. Pollak, "Long-term effects of insulin glargine on the risk of breast cancer," Diabetologia, vol. 54, no. 9, pp. 2254-2262, 2011.

[164] M. K. Leow, "Basal insulin and cardiovascular and other outcomes," The New England Journal of Medicine, vol. 367, no. 18, pp. 1763-1764, 2012.

[165] D. M. Nathan, J. B. Buse, and M. B. Davidson, "Medical management of hyperglycemia in type 2 diabetes: a consensus algorithm for the initiation and adjustment of therapy: a consensus statement of the American diabetes association and the European association for the study of diabetes," Diabetes Care, vol. 32, no. 1, pp. 193-203, 2009.

[166] R. Giannarelli, M. Aragona, A. Coppelli, and S. Del Prato, "Reducing insulin resistance with metformin: the evidence today," Diabetes \& Metabolism, vol. 29, no. 4, part 2, pp. 6-S28, 2003.

[167] R. J. Shaw, K. A. Lamia, D. Vasquez et al., “The kinase LKB1 mediates glucose homeostasis in liver and therapeutic effects of metformin," Science, vol. 310, no. 5754, pp. 1642-1646, 2005.

[168] A. DeCensi, M. Puntoni, P. Goodwin et al., "Metformin and cancer risk in diabetic patients: a systematic review and metaanalysis," Cancer Prevention Research, vol. 3, no. 11, pp. 14511461, 2010.

[169] G. W. D. Landman, N. Kleefstra, K. J. J. van Hateren, K. H. Groenier, R. O. B. Gans, and H. J. G. Bilo, "Metformin associated with lower cancer mortality in type 2 diabetes: ZODIAC-16," Diabetes Care, vol. 33, no. 2, pp. 322-326, 2010.

[170] Z. B. Mei, Z. J. Zhang, C. Y. Liu et al., "Survival benefits of metformin for colorectal cancer patients with diabetes: a systematic review and meta-analysis," PLoS ONE, vol. 9, no. 3, Article ID e91818, 2014.

[171] H. Noto, A. Goto, T. Tsujimoto, and M. Noda, "Cancer risk in diabetic patients treated with metformin: a systematic review and meta-analysis," PLoS ONE, vol. 7, no. 3, Article ID e33411, 2012.

[172] M. Martin and R. Marais, "Metformin: a diabetes drug for cancer, ora cancer drug for diabetics?" Journal of Clinical Oncology, vol. 30, no. 21, pp. 2698-2700, 2012.

[173] R. Rattan, R. Ali Fehmi, and A. Munkarah, "Metformin: an emerging new therapeutic option for targeting cancer stem cells and metastasis," Journal of Oncology, vol. 2012, Article ID 928127, 12 pages, 2012.

[174] E. J. Gallagher and D. Leroith, "Diabetes, cancer, and metformin: connections of metabolism and cell proliferation," Annals of the New York Academy of Sciences, vol. 1243, no. 1, pp. 54-68, 2011.
[175] H. Lee, H. J. Park, C.-S. Park et al., "Response of breast cancer cells and cancer stem cells to metformin and hyperthermia alone or combined," PLoS ONE, vol. 9, no. 2, Article ID e87979, 2014.

[176] D. G. Hardie, "Neither LKB1 nor AMPK are the direct targets of metformin," Gastroenterology, vol. 131, no. 3, pp. 973-975, 2006.

[177] R. J. O. Dowling, M. Zakikhani, I. G. Fantus, M. Pollak, and N. Sonenberg, "Metformin inhibits mammalian target of rapamycin-dependent translation initiation in breast cancer cells," Cancer Research, vol. 67, no. 22, pp. 10804-10812, 2007.

[178] M. Zakikhani, R. Dowling, I. G. Fantus, N. Sonenberg, and M. Pollak, "Metformin is an AMP kinase-dependent growth inhibitor for breast cancer cells," Cancer Research, vol. 66, no. 21, pp. 10269-10273, 2006.

[179] I. N. Alimova, B. Liu, Z. Fan et al., "Metformin inhibits breast cancer cell growth, colony formation and induces cell cycle arrest in vitro," Cell Cycle, vol. 8, no. 6, pp. 909-915, 2009.

[180] B. Liu, Z. Fan, S. M. Edgerton et al., "Metformin induces unique biological and molecular responses in triple negative breast cancer cells," Cell Cycle, vol. 8, no. 13, pp. 2031-2040, 2009.

[181] M. Zakikhani, R. J. O. Dowling, N. Sonenberg, and M. N. Pollak, "The effects of adiponectin and metformin on prostate and colon neoplasia involve activation of AMP-activated protein kinase," Cancer Prevention Research, vol. 1, no. 5, pp. 369-375, 2008.

[182] V. N. Anisimov, L. M. Berstein, P. A. Egormin et al., "Effect of metformin on life span and on the development of spontaneous mammary tumors in HER-2/neu transgenic mice," Experimental Gerontology, vol. 40, no. 8-9, pp. 685-693, 2005.

[183] M. B. Schneider, H. Matsuzaki, J. Haorah et al., "Prevention of pancreatic cancer induction in hamsters by metformin," Gastroenterology, vol. 120, no. 5, pp. 1263-1270, 2001.

[184] C. Algire, M. Zakikhani, M.-J. Blouin, J. H. Shuai, and M. Pollak, "Metformin attenuates the stimulatory effect of a high-energy diet on in vivo LLC1 carcinoma growth," Endocrine-Related Cancer, vol. 15, no. 3, pp. 833-839, 2008.

[185] J. M. M. Evans, L. A. Donnelly, A. M. Emslie-Smith, D. R. Alessi, and A. D. Morris, "Metformin and reduced risk of cancer in diabetic patients," British Medical Journal, vol. 330, no. 7503, pp. 1304-1305, 2005.

[186] S. Jiralerspong, S. L. Palla, S. H. Giordano et al., "Metformin and pathologic complete responses to neoadjuvant chemotherapy in diabetic patients with breast cancer," Journal of Clinical Oncology, vol. 27, no. 20, pp. 3297-3302, 2009.

[187] Z.-J. Zhang and S. Li, "The prognostic value of metformin for cancer patients with concurrent diabetes: a systematic review and meta-analysis," Diabetes, Obesity and Metabolism, vol. 16, no. 8, pp. 707-710, 2014.

[188] R. J. Stevens, R. Ali, C. R. Bankhead et al., "Cancer outcomes and all-cause mortality in adults allocated to metformin: systematic review and collaborative meta-analysis of randomised clinical trials," Diabetologia, vol. 55, no. 10, pp. 2593-2603, 2012.

[189] N. F. Col, L. Ochs, V. Springmann, A. K. Aragaki, and R. T. Chlebowski, "Metformin and breast cancer risk: a metaanalysis and critical literature review," Breast Cancer Research and Treatment, vol. 135, no. 3, pp. 639-646, 2012.

[190] H. Hauner, "The mode of action of thiazolidinediones," Diabetes/Metabolism Research and Reviews, vol. 18, supplement 2, pp. S10-S15, 2002.

[191] D. Panigrahy, S. Huang, M. W. Kieran, and A. Kaipainen, "PPAR $\gamma$ as a therapeutic target for tumor angiogenesis and 
metastasis," Cancer Biology and Therapy, vol. 4, no. 7, pp. 687693, 2005.

[192] A. Rubenstrunk, R. Hanf, D. W. Hum, J.-C. Fruchart, and B. Staels, "Safety issues and prospects for future generations of PPAR modulators," Biochimica et Biophysica Acta (BBA)Molecular and Cell Biology of Lipids, vol. 1771, no. 8, pp. 10651081, 2007.

[193] K. Ohta, T. Endo, K. Haraguchi, J. M. Hershman, and T. Onaya, "Ligands for peroxisome proliferator-activated receptor $\gamma$ inhibit growth and induce apoptosis of human papillary thyroid carcinoma cells," The Journal of Clinical Endocrinology \& Metabolism, vol. 86, no. 5, pp. 2170-2177, 2001.

[194] C. Blanquicett, J. Roman, and C. M. Hart, "Thiazolidinediones as anti-cancer agents," Cancer Therapy, vol. 6, pp. 25-34, 2008.

[195] J. Berger and D. E. Moller, "The mechanisms of action of PPARs," Annual Review of Medicine, vol. 53, pp. 409-435, 2002.

[196] D. Panigrahy, L. Q. Shen, M. W. Kieran, and A. Kaipainen, "Therapeutic potential of thiazolidinediones as anticancer agents," Expert Opinion on Investigational Drugs, vol. 12, no. 12, pp. 1925-1937, 2003.

[197] D. Panigrahy, S. Singer, L. Q. Shen et al., "PPAR $\gamma$ ligands inhibit primary tumor growth and metastasis by inhibiting angiogenesis," The Journal of Clinical Investigation, vol. 110, no. 7, pp. 923-932, 2002.

[198] E. Saez, J. Rosenfeld, A. Livolsi et al., "PPAR $\gamma$ signaling exacerbates mammary gland tumor development," Genes \& Development, vol. 18, no. 5, pp. 528-540, 2004.

[199] K. Yang, K.-H. Fan, S. A. Lamprecht et al., "Peroxisome proliferator-activated receptor $\gamma$ agonist troglitazone induces colon tumors in normal C57BL/6J mice and enhances colonic carcinogenesis in Apc ${ }^{1638 \mathrm{~N} /+} \mathrm{Mlhl}^{+/-}$double mutant mice," International Journal of Cancer, vol. 116, no. 4, pp. 495-499, 2005.

[200] E. Saez, P. Tontonoz, M. C. Nelson et al., "Activators of the nuclear receptor PPAR $\gamma$ enhance colon polyp formation," Nature Medicine, vol. 4, no. 9, pp. 1058-1061, 1998.

[201] C. Koro, S. Barrett, and N. Qizilbash, "Cancer risks in thiazolidinedione users compared to other anti-diabetic agents," Pharmacoepidemiology and Drug Safety, vol. 16, no. 5, pp. 485492, 2007.

[202] R. Govindarajan, L. Ratnasinghe, D. L. Simmons et al., “Thiazolidinediones and the risk of lung, prostate, and colon cancer in patients with diabetes," Journal of Clinical Oncology, vol. 25, no. 12, pp. 1476-1481, 2007.

[203] M. E. Ramos-Nino, C. D. MacLean, and B. Littenberg, "Association between cancer prevalence and use of thiazolidinediones: results from the vermont diabetes information system," $B M C$ Medicine, vol. 5, article 17, 2007.

[204] X. He, F. J. Esteva, J. Ensor, G. N. Hortobagyi, M.-H. Lee, and S.-C. J. Yeung, "Metformin and thiazolidinediones are associated with improved breast cancer-specific survival of diabetic women with HER2+ breast cancer," Annals of Oncology, vol. 23, no. 7, Article ID mdr534, pp. 1771-1780, 2012.

[205] C.-H. Tseng, "Pioglitazone does not affect the risk of ovarian cancer: analysis of a nationwide reimbursement database in Taiwan," Gynecologic Oncology, vol. 131, no. 1, pp. 135-139, 2013.

[206] M. Monami, C. Lamanna, N. Marchionni, and E. Mannucci, "Rosiglitazone and risk of cancer: a meta-analysis of randomized clinical trials," Diabetes Care, vol. 31, no. 7, pp. 1455-1460, 2008.
[207] M. Monami, I. Dicembrini, and E. Mannucci, "Thiazolidinediones and cancer: results of a meta-analysis of randomized clinical trials," Acta Diabetologica, vol. 51, no. 1, pp. 91-101, 2014. 


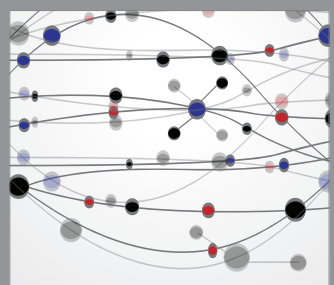

The Scientific World Journal
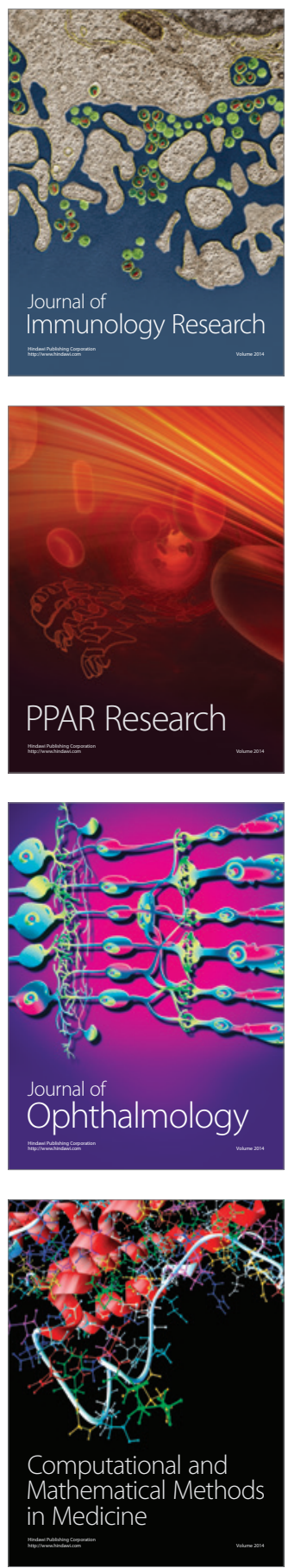

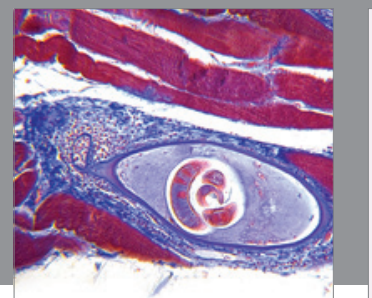

Gastroenterology

Research and Practice
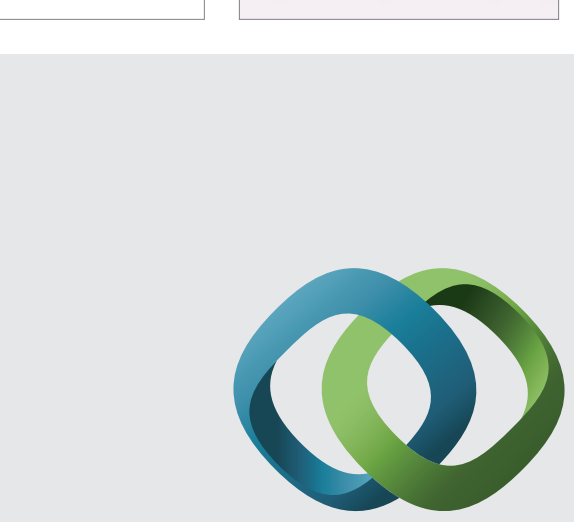

\section{Hindawi}

Submit your manuscripts at

http://www.hindawi.com
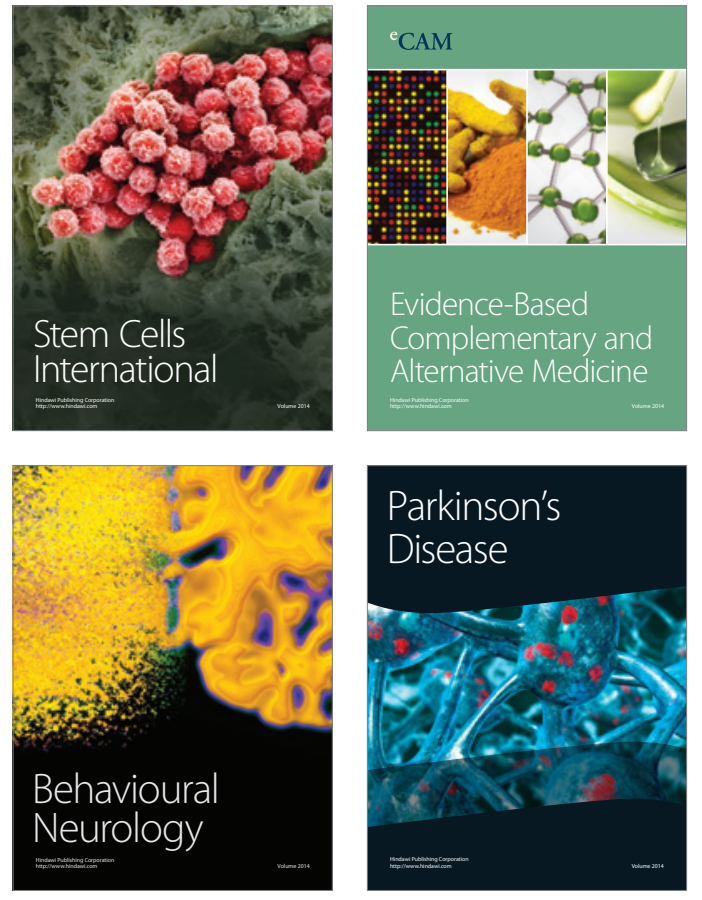
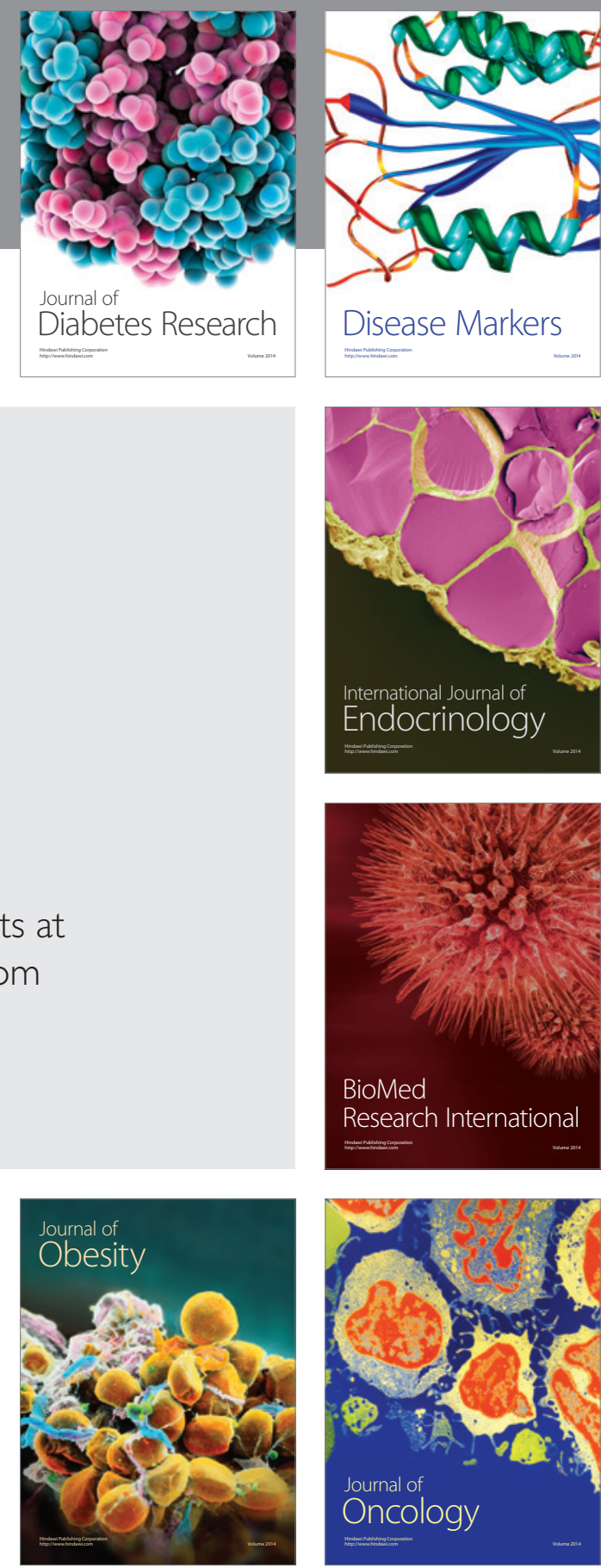

Disease Markers
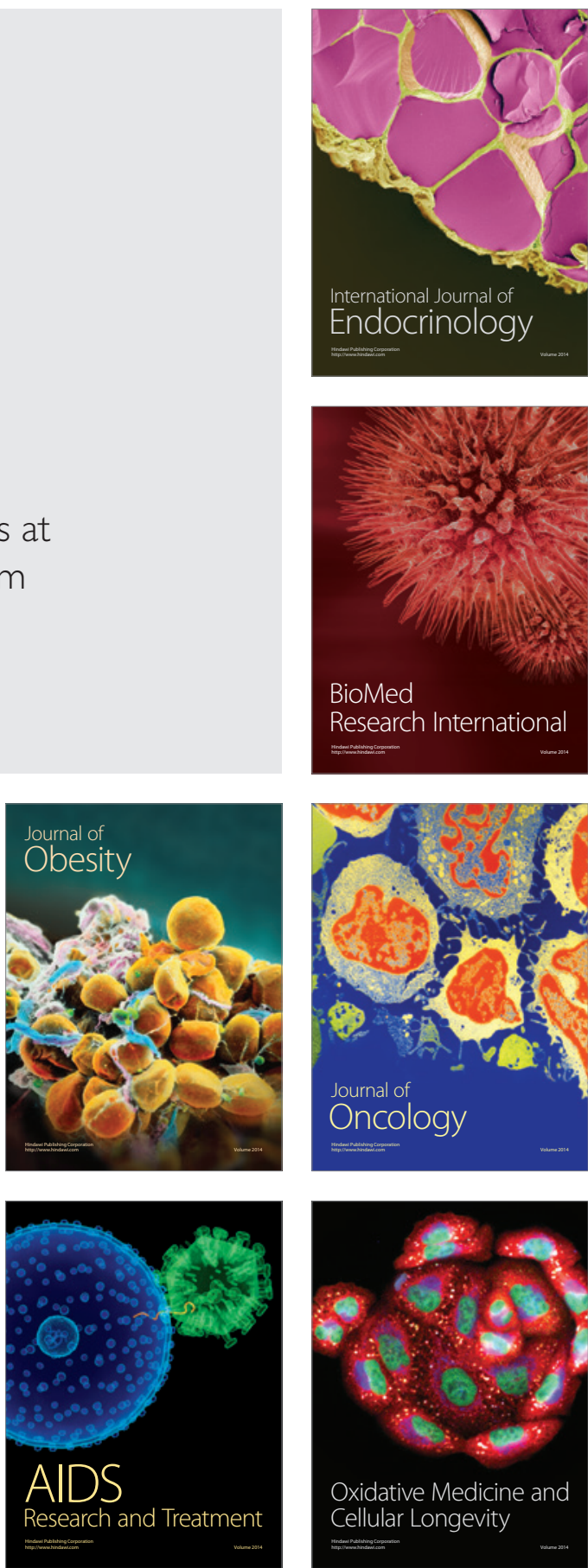